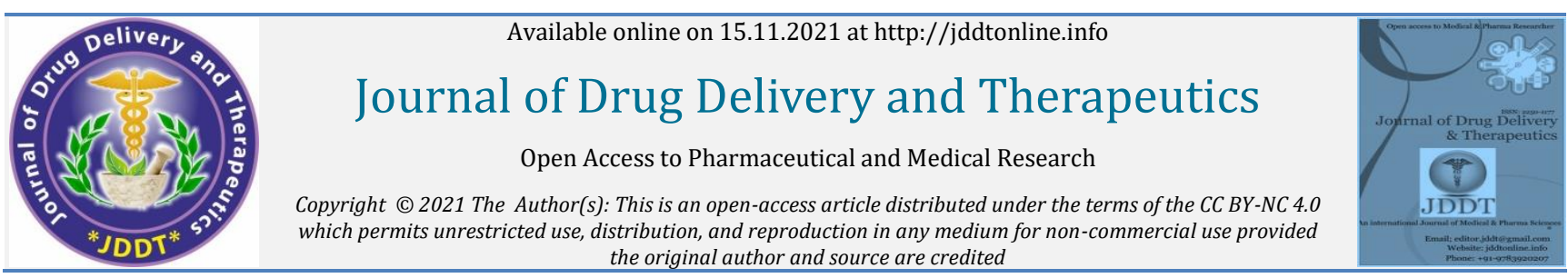
the original author and source are credited

Research Article

\title{
Effect of Mucuna pruriens and Millettia pinnata (Fabaceae) minerals on some isolated organs of envenomated and treated Oryctolagus cuniculus
}

\author{
OKOU Obou Constantin1,2*, KOFFI Allali Eugène ${ }^{1,2}$, AKRÉ Djako Sosthène Thierry ${ }^{1}$, BINGO Guy Childeric ${ }^{1}$, \\ DJAMAN Allico Joseph 2
}

${ }^{1}$ Department of Biochemistry and Microbiology, Jean Lorougnon Guédé University, Côte d'Ivoire.

${ }^{2}$ Department of Biology-Health, Félix Houphouët-Boigny University Abidjan, Côte d'Ivoire.

\section{Article Info:}

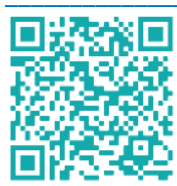

\section{Article History:}

Received 10 September 2021

Reviewed 19 October 2021

Accepted 24 October 2021

Published 15 November 2021

Cite this article as:

OKOU OC, KOFFI AE, AKRÉ DST, BINGO GC, DJAMAN AJ, Effect of Mucuna pruriens and Millettia pinnata (Fabaceae) minerals on some isolated organs of envenomated and treated Oryctolagus cuniculus, Journal of Drug Delivery and Therapeutics. 2021; 11(6):40-47

DOI: http://dx.doi.org/10.22270/jddt.v11i6.5035

*Address for Correspondence:

OKOU Obou Constantin, Assistant Professor, Department of Biochemistry and Microbiology, Jean Lorougnon Guédé University, Côte d'Ivoire.

\begin{abstract}
The general objective of this study was to evaluate the antivenom effect of minerals from two plants on some vital organs (heart, liver, kidneys and lungs) of rabbits. It was carried out with 36 rabbits (19 males and 17 females) divided into portions E1, E2 and E3. E1 consisted of 2 control lots ( 3 males and 3 females), and 1 experimental lot ( 2 males and 1 female). E2 comprised 7 batches of rabbits ( 2 males and 1 female). E3 consisted of 2 batches of 3 females. Naja nigricollis venom was injected for approximately 20-30 minutes to the animals in the experimental batch of E1, and to those in E2 and E3. Then, E2 and E3 were treated preventively and curatively with minerals, respectively. After the determination of their biochemical and hematological parameters, they were necropsied separately and then their organs were removed, weighed and their appearance was studied. The study revealed that the venom of Naja nigricollis was the cause of death of all the animals of the experimental batch of E1. On the other hand, the use of P2 and P3 as a preventive measure was able to save 1 out of 3 and 3 individuals respectively from the venom. As for P3 as a curative measure, it kept alive 2 out of 3 individuals against the venom. Thus, for the development of anti-venomous phytomedicine, it would be advisable to use the minerals from P3 (ash of Millettia pinnata).
\end{abstract}

Keywords: Antivenomous, minerals, Millettia pinnata, Naja nigricollis, phytomedicine

\section{INTRODUCTION}

Envenomation is the introduction into the body of a toxic substance, the venom, due to the bite of a snake, the sting of a scorpion, a wasp, etc. The most dangerous is that caused by snake bites ${ }^{1,17}$. Indeed, the venom contains a complex mixture of enzymes, peptides and proteins of low relative molecular weight, with specific chemical and biological activities, which can lead to death through neurological and/or hematological disorders ${ }^{14,17}$. This case of envenomation is a problem affecting the five continents of the world. Worldwide, the annual incidence of snakebites exceeds six million $4,12,9$. However, Africa records more than one million bites causing 600,000 cases of envenomation. Also in Africa, nearly 250,000 patients are treated, nevertheless, there are more than 20,000 deaths ${ }^{7,8}$.

In Africa, in general, the venomous snakes responsible for all these disasters are mostly Viperidae and Elapidae. The Viperidae (vipers) are the most widespread of the venomous species and do the most damage while the Elapidae (naja, mamba) are the most dangerous of the snakes because of the high degree of toxicity of their venom ${ }^{19}$. It is traditional to oppose cobraic envenomations, essentially neurotoxic, and viperine envenomations, dominated by necrosis and hemorrhagic syndromes. In practice, this distinction must be qualified ${ }^{8}$. In effect, the diversity of substances contained in the venoms of the species of these two families of snakes, vary according to the species and even between individuals of the same species, which makes certain species exceptional in the action of their venom. Among these exceptions is the venom of Naja nigricollis (spitting cobra), one of the most dangerous and representative species of Elapidae in Africa. Its venom contains cytoxins that target certain blood cells and those of certain organs such as the heart. Its action on these organs, creates dysfunctions whose effects associated with those of these neurotoxins could have a serious impact on the victim's breathing and lead to death ${ }^{15,6}$.

Given the diversity and severity of the consequences of snakebites, various means of treatment are used, depending on the geographical situation, the beliefs of the populations, the cost, the precocity and the specificity ${ }^{10}$. These various means of treatment involve two types of medicine. Modern medicine, whose treatment principle is based on the earliest possible administration of anti-venomous serum, considered too specific, more expensive, less preservable and less accessible, but whose effectiveness has been scientifically 
proven. As for traditional medicine, it uses plants or other natural substances that are more accessible, preservable and effective according to a belief generally based on traditional practitioners and testimonies from a large number of patients ${ }^{13}$.

According to the World Health Organization in 2013, about $80 \%$ of the populations of developing countries use traditional medicine and in particular herbal medicine for their health care needs. In fact, the African floral heritage is very rich in medicinal plants with proven effectiveness. It is full of nearly 5000 medicinal species ${ }^{1,20}$. In West Africa, particularly in Benin, $80 \%$ of people bitten by snakes report that they use traditional treatment rather than modern Western medicine ${ }^{5,16}$. In Côte d'Ivoire, some researchers report that the roots of Securidaca longepedunculata (Polygalaceae) can be used in cases of envenomation by Elapidae ${ }^{18,22}$. Also in Côte d'Ivoire, specifically in the Bouaké region, some traditional practitioners use Millettia pinnatta and Mucuna pruriens, two species of the Fabaceae family for envenomations.

It is in the concern to exploit rationally this heritage, to give a scientific basis to the use of these plants and to bring its contribution to the discovery of new heads of series of drugs that this present study was led.

\section{MATERIALS AND METHODS}

\section{MATERIALS}

\section{Biological materials}

The plant material consists of Mucuna pruriens and Millettia pinnata. They were harvested in the month of December 2019 in Bouaké (Central Côte d'Ivoire).

\section{Animal material}

For this study, 36 rabbits, 19 males and 17 females of the Hyplus breed, aged 2 and a half months, were purchased from a breeder in the locality of Daloa (Côte d'Ivoire). After the acclimatization period, the weight of the rabbits varied between 1.45 and $2.4 \mathrm{~kg}$. Besides this animal model, viper skulls and Naja nigricollis venom were also used. The viper skulls were provided by a medicodrugist while the Naja nigricollis venom was provided by the Pasteur Institute of Adiopodoumé (Côte d'Ivoire, West Africa).

\section{METHODS}

\section{Method of preparation of minerals}

For its realization, the various plants were harvested in Bouaké, washed, cut up and then dried in the sun at room temperature for one week. Then, the plant organs were dried in an oven at a temperature of $70{ }^{\circ} \mathrm{C}$ for three days. After this drying time, the organs (plant and animal) obtained were incinerated in a muffle furnace for 13 hours at $550{ }^{\circ} \mathrm{C}$. The ashes obtained were weighed with a precision balance. They are smooth except for the viper skull which is rough. The colors vary from gray to brown.

The combination of the ashes from the various biological products resulted in the following potions:

- P1 made up of the ashes of the two plants and the skull of viper;

- P2, P3 and P4 are constituted respectively and only of ash of Mucuna pruriens, Millettia pinnata and the skull of viper;

- P5 is composed of the ashes of Mucuna pruriens and Millettia pinnata;
- P6 consists of the ashes of the skull of viper and Mucuna pruriens;

- P7 is the ash of the viper skull and Millettia pinnata.

\section{Calculation of incineration efficiency}

The formula below was used to calculate the dry matter weight of the organs used.

$$
\text { Tc }=\frac{\text { Mass of ash }}{\text { Dry } \text { matter }} \times 100
$$

Tc: Ash content

\section{Method of scarification of experimental batches}

To scarify the experimental batches, the following potions:

- P1 was used for batch 2 (preventive) and batch 9 (curative);

- P2 has been used for batch 4;

- P3 served for batch 4 (preventive title) and batch 10 (curative title);

- P4 was used for batch 5;

- P5 served for batch 6;

- P6 has been used for batch 7;

- P7 was used for batch 8 .

Each experimental batch consisted of two males and one female. However, prior to scarification, the affected areas (toes of the left paw and tarsus of the right paw) were bared with a pair of scissors. Then, a separate amount of $0.45 \mathrm{mg}$ of the previously prepared potion was applied to each affected area of each given batch. The experimental tests started four days after the scarification (for preventive test) and three days after for curative test.

\section{Method of carrying out the experimental tests}

For the experimental tests, a quantity of $2 \mathrm{mg}$ of venom crystals was dissolved in $0.5 \mathrm{~mL}$ of physiological solution in order to obtain a concentration of $4 \mathrm{mg} / \mathrm{mL}$. This is the concentration that was injected into the rabbits of the experimental batch for about twenty to thirty minutes. According to ${ }^{13}$, the median lethal dose for a $2 \mathrm{~kg}$ rabbit is 2 $\mathrm{mg} / \mathrm{kg}$ body weight by intra-muscular injection.

\section{Methods of organ procurement}

To collect these organs, control and experimental rabbits were autopsied and then organs such as heart, liver, lungs and kidneys were isolated and weighed in the laboratory. Then, the appearance of these various organs was studied.

\section{RESULTS AND DISCUSSION}

\section{RESULTS}

\section{General appearance of isolated rabbit organs}

Figures 1, 2, 3, and 4 are those of isolated organs (heart, liver, kidney, and lungs) of control, envenomated treated (preventive and curative title), and envenomated untreated rabbits, respectively. The organs isolated from control rabbits (Figures 1A, 2A, $3 \mathrm{~A}$ and $4 \mathrm{~A}$ ) and those from envenomated and treated rabbits (Figures 1B, 2B, 3B and 4B) have the same appearance. In effect, they are reddish for the heart (Figure 1A and $1 \mathrm{~B}$ ) and kidneys (Figure 3A and $3 \mathrm{~B}$ ), brown for the liver (Figure 2A and 2B) and purplish red for the lungs (Figure $4 \mathrm{~A}$ and $4 \mathrm{~B}$ ). They also have a firm and elastic consistency. However, the organs of untreated envenomated rabbits (Figures 1C, 2C, 3C, and 4C) are dark red for the heart (Figure 1C) and kidneys (Figure 3C), purplish red for the liver (Figure 2C), and orange-red for the 


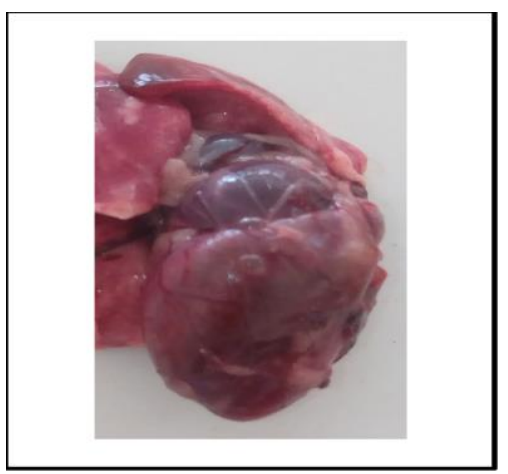

A

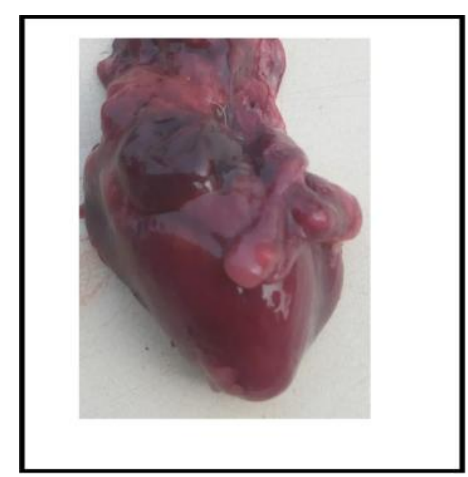

B

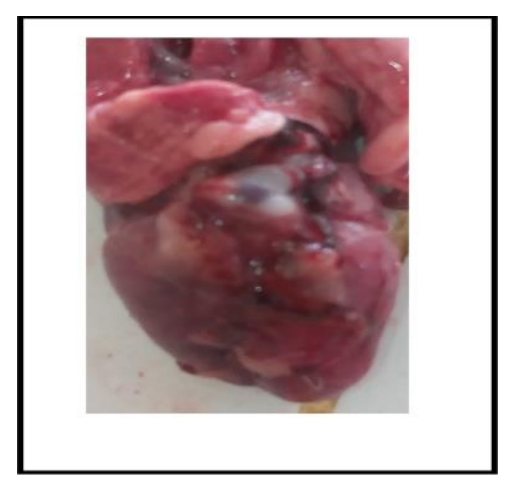

C

Figure 1: Isolated hearts of rabbits

A: Isolated heart of control rabbit, B: Isolated heart of envenomed and treated rabbit, C: Isolated heart of untreated envenomed rabbit

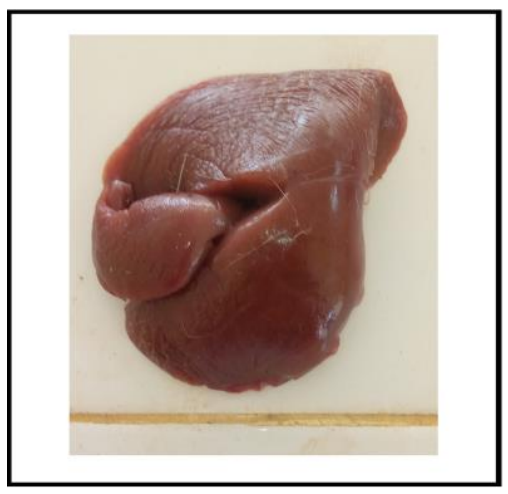

A

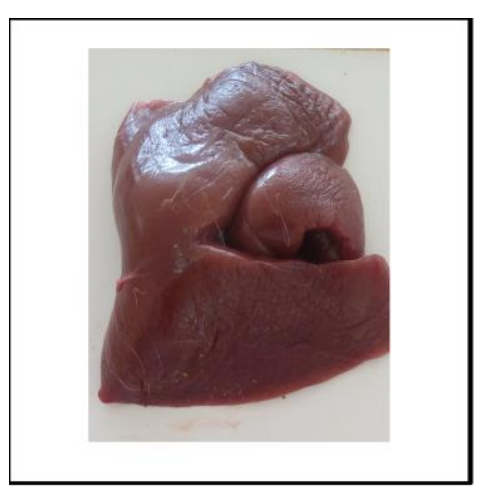

B

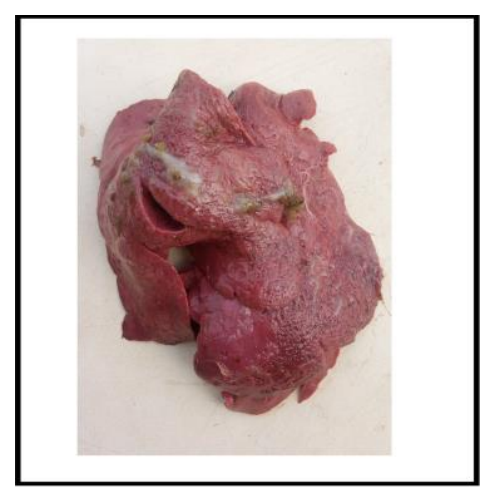

C

Figure 2: Isolated livers of rabbits

A: Isolated liver of control rabbit, B: Isolated liver of envenomed and treated rabbit, C: Isolated liver of untreated envenomed rabbit

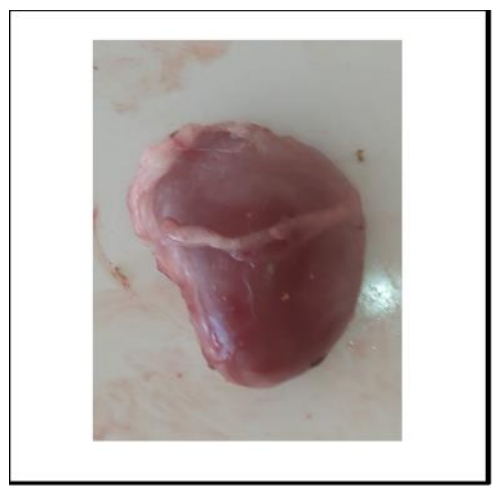

A

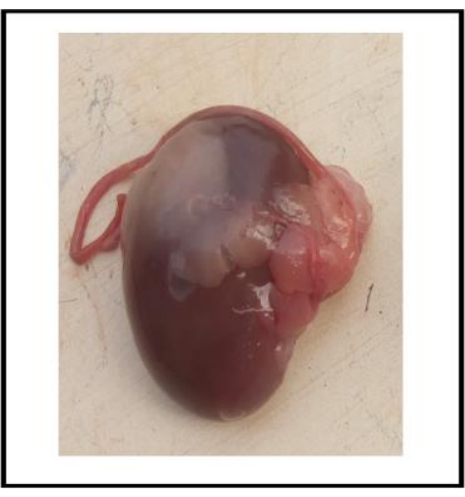

B

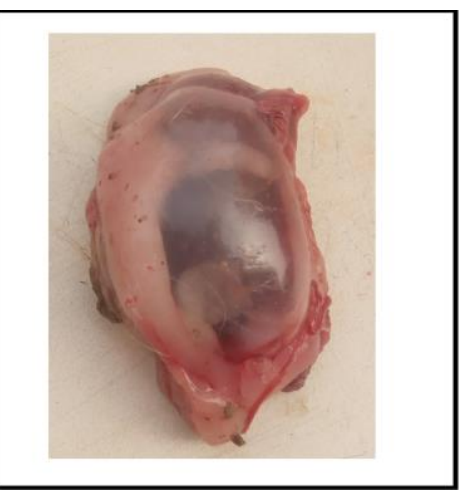

C

Figure 3: Isolated kidneys of rabbits

A: Isolated kidney of control rabbit, B: Isolated kidney of envenomed and treated rabbit, C: Isolated kidney of untreated envenomed rabbit 


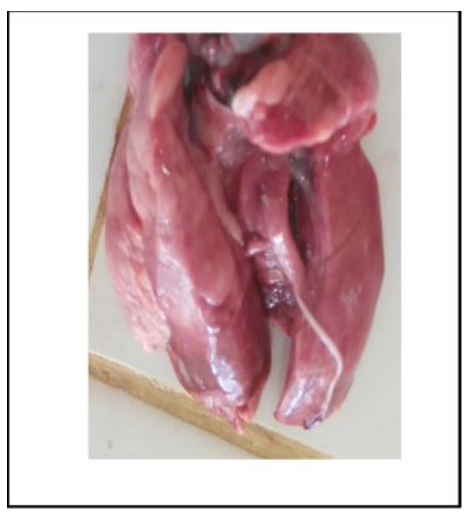

A

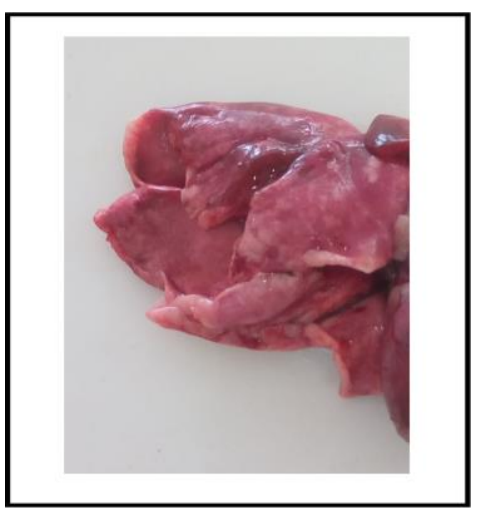

B

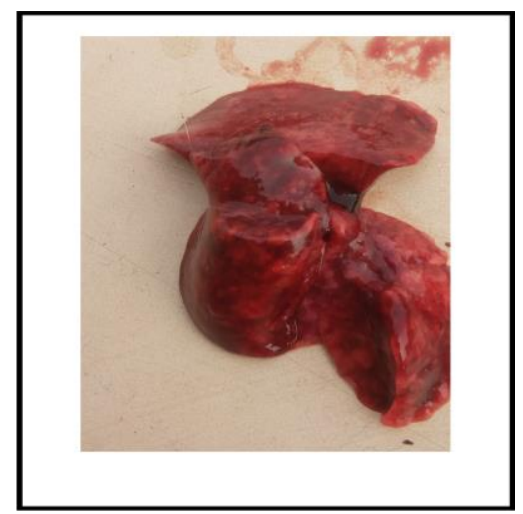

C

Figure 4: Isolated lungs of rabbits

A: Isolated lung of control rabbit, B: Isolated lung of envenomed and treated rabbit, C: Isolated lung of untreated envenomed rabbit

Isolated organ weights of untreated control and envenomed rabbits

In Table 1 are given the results of the weighing of organs isolated from control and envenomed untreated rabbits (portion E1). This weighing allowed to have for each organ the following reference values:

- for the heart, they vary from 4.51 to $8.70 \mathrm{~g}$ for males and from 4.48 to $6.63 \mathrm{~g}$ for females

- for the liver, they range from 49.68 to $64.30 \mathrm{~g}$ for males and from 51.56 to $64.66 \mathrm{~g}$ for females.

- for the kidneys, they are 4.94 to $6 \mathrm{~g}$ for males and 5.01 to $5.95 \mathrm{~g}$ for females.
- for males and females, they are respectively from 6.50 to $8.03 \mathrm{~g}$ and from 5.66 to $7.07 \mathrm{~g}$ for the lungs.

As for the organ weights of the envenomed rabbits, it indicates that:

- the heart and lungs of the male M18 which are respectively $10.5 \mathrm{~g}$ and $8.5 \mathrm{~g}$ and those of the female $\mathrm{F} 4 \mathrm{of} 7.02 \mathrm{~g}$ and 8.45 $\mathrm{g}$ are above their respective norms $(4.51-8.70 \mathrm{~g}$ and 6.50 8.03 g, and 4.48-6.63 g and 5.66-7.07 g); whereas those of the male M19 ( $7.5 \mathrm{~g}$ and $8 \mathrm{~g}$ ) are normal;

- the liver and kidneys of both males (70.9 $\mathrm{g}$ and $81.3 \mathrm{~g}$ for liver, and $6.9 \mathrm{~g}$ and $8.1 \mathrm{~g}$ for kidneys) and of the female (69.4 $\mathrm{g}$ for liver and $6.8 \mathrm{~g}$ for kidneys) are higher than their respective reference values (49.68-64.30 $\mathrm{g}$ and 51.56-64.66 $\mathrm{g}$ for liver, and 4.94-6 $\mathrm{g}$ and 5.01-5.95 $\mathrm{g}$ for kidneys).

Table 1: Organ weights isolated from control and envenomed rabbits

\begin{tabular}{|c|c|c|c|c|c|c|c|c|c|c|c|c|c|c|}
\hline \multirow[b]{2}{*}{$\begin{array}{c}\text { M1 } \\
0\end{array}$} & \multicolumn{5}{|c|}{ Lot 11: Males controls } & \multicolumn{5}{|c|}{ Lot 12: Females controls } & \multirow[b]{2}{*}{$\begin{array}{c}\text { Referen } \\
\text { ce } \\
\text { values }\end{array}$} & \multicolumn{3}{|c|}{$\begin{array}{c}\text { Lot 1: } \\
\text { Envenomed }\end{array}$} \\
\hline & $\begin{array}{c}\text { M1 } \\
6\end{array}$ & $\begin{array}{c}\text { M1 } \\
7\end{array}$ & M & $\mathrm{Sd}$ & $\begin{array}{c}\text { Referen } \\
\text { ce } \\
\text { values }\end{array}$ & $\mathrm{F} 1$ & $\begin{array}{c}\mathrm{F} 1 \\
0\end{array}$ & $\begin{array}{c}\mathrm{F} 1 \\
2\end{array}$ & M & $\mathrm{Sd}$ & & $\begin{array}{c}\text { M1 } \\
8\end{array}$ & $\begin{array}{c}\text { M1 } \\
9\end{array}$ & $\mathrm{~F} 4$ \\
\hline 2.4 & $\begin{array}{c}1.4 \\
5\end{array}$ & 1.9 & $\begin{array}{c}1.916 \\
7\end{array}$ & $\begin{array}{c}0.475 \\
2\end{array}$ & $\begin{array}{l}1.44- \\
2.39\end{array}$ & 2 & 1.7 & 2 & 1.9 & $\begin{array}{c}0.173 \\
2\end{array}$ & $\begin{array}{l}1.73- \\
2.07\end{array}$ & $\begin{array}{c}1.8 \\
5\end{array}$ & 1.9 & 1.9 \\
\hline 8.7 & $\begin{array}{c}4.5 \\
1\end{array}$ & 6.6 & $\begin{array}{c}6.603 \\
3\end{array}$ & 2.095 & $\begin{array}{l}4.51- \\
8.70\end{array}$ & $\begin{array}{c}6.6 \\
6\end{array}$ & $\begin{array}{c}4.5 \\
1\end{array}$ & 5.5 & $\begin{array}{c}5.556 \\
7\end{array}$ & $\begin{array}{c}1.076 \\
1\end{array}$ & $\begin{array}{l}4.48- \\
6.63\end{array}$ & $\begin{array}{c}10 . \\
5\end{array}$ & 7.5 & $\begin{array}{c}7.0 \\
2\end{array}$ \\
\hline 65 & $\begin{array}{c}50 . \\
7\end{array}$ & $\begin{array}{c}55 . \\
3\end{array}$ & 56.99 & 7.313 & $\begin{array}{l}49.68- \\
64.30\end{array}$ & $\begin{array}{c}60 . \\
7\end{array}$ & $\begin{array}{c}50 . \\
7\end{array}$ & 63 & $\begin{array}{c}58.11 \\
3\end{array}$ & $\begin{array}{c}6.550 \\
5\end{array}$ & $\begin{array}{c}51.56- \\
64.66\end{array}$ & $\begin{array}{c}70 . \\
9\end{array}$ & $\begin{array}{c}81 . \\
3\end{array}$ & $\begin{array}{c}69 . \\
4\end{array}$ \\
\hline 6 & $\begin{array}{c}4.9 \\
4\end{array}$ & $\begin{array}{c}5.4 \\
7\end{array}$ & 5.47 & 0.53 & $4.94-6$ & 5.7 & $\begin{array}{c}4.9 \\
4\end{array}$ & 5.8 & 5.48 & $\begin{array}{c}0.470 \\
3\end{array}$ & $\begin{array}{l}5.01- \\
5.95\end{array}$ & 6.9 & 8.1 & 6.8 \\
\hline 8.1 & 7.1 & 6.6 & $\begin{array}{c}7.266 \\
7\end{array}$ & $\begin{array}{c}0.763 \\
8\end{array}$ & $\begin{array}{l}6.50- \\
8.03\end{array}$ & 6.3 & 7.1 & 5.7 & $\begin{array}{c}6.366 \\
7\end{array}$ & $\begin{array}{c}0.702 \\
4\end{array}$ & $\begin{array}{l}5.66- \\
7.07\end{array}$ & 8.5 & 8 & $\begin{array}{c}8.4 \\
5\end{array}$ \\
\hline & & & & & & & & & & & State & $\mathrm{D}$ & D & $\mathrm{D}$ \\
\hline
\end{tabular}

F=Female $; M=$ Male $; \mathrm{M}=$ Mean $;$ Sd = Standard deviation $;$ Dark grey and bold: High value $;$ State D= Dead 
Isolated organ weights of envenomated preventively treated rabbits

In Table 2, the reference values are found after weighing the weight of the organs of the rabbits treated preventively and envenomed (portion E2). The analysis of the weights of the vital organs of the preventively treated and envenomed rabbits reveals that:

- in batch 2 , both males and the female have increased liver, kidney and lung size $(65 ; 70.3$ and $67.4 \mathrm{~g}$ for liver, 8.4 and 8 $\mathrm{g}$ for kidney, and 13.9 and $13 \mathrm{~g}$ for lung, respectively); while the heart is enlarged in one male $(10.2 \mathrm{~g})$ and one female (9.8 g), and normal in one male ( $8.6 \mathrm{~g})$ This batch is characterized by the death of all individuals;

- in lot 3, in the female, the liver (66.4 g) and the lungs ( 9.65 g) are large. The same is true for the kidneys of a male (6.55 g). On the other hand, the liver ( $43.8 \mathrm{~g}$ ) of a male and the kidneys of the female (3.85 g) are small compared to their respective norms (49.68-64.30 g and 5.01-5.95 g). Apart from these different observations, the heart is normal in all individuals of the batch. In addition, one male has all his vital organs normal. In this batch, one male survived;

- in lot 4 , the volume of the kidneys is concomitantly high in the two males and the female (respectively $10.2 \mathrm{~g} ; 6.51 \mathrm{~g}$ and $7.4 \mathrm{~g}$ ); as are those of the heart and lungs in the female (respectively $7 \mathrm{~g}$ and $14.1 \mathrm{~g}$ ). Besides these different findings, the liver is normal in all three individuals while the heart and lungs are normal in the two males of the lot. The individuals of this batch are all survivors;

- in lot 5, the liver and kidneys have high values simultaneously in both males (respectively $70.9 \mathrm{~g}$ and $6.9 \mathrm{~g}$ for one male, and $81.3 \mathrm{~g}$ and $8.1 \mathrm{~g}$ for the other) as well as the lungs in one male $(8.5 \mathrm{~g})$ and the female $(8.45 \mathrm{~g})$ and the heart $(10.5 \mathrm{~g})$ in one male. Except for these remarks, heart, liver and kidney are within standards in the female while heart and lung are within standards in one male of the lot. In this lot, all animals died;

- in batch 6 , the liver, kidneys and lungs are enlarged at the same time in all individuals of the batch as is the heart in the female. Regardless of these observations, the heart is normal in both males of the batch. This batch is distinguished by the death of all individuals;

- in lot 7, the lungs are large in all the animals of the lot $(9.52$ $\mathrm{g}$ and $8.44 \mathrm{~g}$ for the two males and $9.24 \mathrm{~g}$ for the female) as are the kidneys in one male $(6.1 \mathrm{~g})$ and one female $(12.3 \mathrm{~g})$, and the liver in one male (65.5 g). However, kidneys are small in one male $(4.47 \mathrm{~g})$ of the lot. Apart from these findings, the heart is normal in all individuals of the lot as well as the liver in one male and one female. The two males in the batch are alive;

- In batch 8 , the heart (7.1 g) and kidneys (7.7 g) in the female, and the lungs in one male $(8.5 \mathrm{~g}$ and $8.9 \mathrm{~g}$ respectively) were large, but the other organs were normal for the animals in the batch. One male from this lot survived. 
OKOU et al

Journal of Drug Delivery \& Therapeutics. 2021; 11(6):40-47

Table 2: Isolated organs of rabbits treated as a preventive measure and envenomed

\begin{tabular}{|c|c|c|c|c|c|c|c|c|c|c|c|c|c|c|c|c|c|c|c|c|c|}
\hline & \multicolumn{3}{|l|}{ Lot 2} & \multicolumn{3}{|l|}{ Lot 3} & \multicolumn{3}{|l|}{ Lot 4} & \multicolumn{3}{|l|}{ Lot 5} & \multicolumn{3}{|l|}{ Lot 6} & \multicolumn{3}{|l|}{ Lot 7} & \multicolumn{3}{|l|}{ Lot 8} \\
\hline & $\overline{\mathrm{M} 3}$ & M13 & F3 & M8 & M11 & F7 & M14 & M9 & F11 & M1 & M6 & F6 & M5 & M12 & F14 & M15 & M2 & F13 & M17 & M4 & F2 \\
\hline Weight (Kg) & 2.35 & 1.65 & 1.8 & 1.8 & 1.9 & 2.04 & 1.75 & 2.05 & 1.8 & 1.85 & 1.9 & 1.9 & 1.7 & 2.3 & 1.74 & 1.85 & 1.9 & 2 & 1.9 & 1.85 & 1.9 \\
\hline Heart (g) & 8.6 & 10.2 & 9.8 & 5.54 & 6.24 & 5.22 & 7.4 & 8.5 & 7 & 7.5 & 10.5 & 5.02 & 8.52 & 7.82 & 7.12 & 6.07 & 5.07 & 5.33 & 6.5 & 5 & 7.1 \\
\hline Liver (g) & 65 & 70.3 & 67.4 & 52.4 & 43.8 & 66.4 & 51.2 & 51.3 & 58.7 & 70.9 & 81.3 & 60.4 & 66.7 & 66 & 65.3 & 56.5 & 65.5 & 53.5 & 49.8 & 55.4 & 61.1 \\
\hline Kidneys (g) & 8.4 & 8 & 8 & 6 & 6.55 & 3.85 & 10.2 & 6.51 & 7.4 & 6.9 & 8.1 & 5.8 & 7.4 & 6.99 & 6.57 & 6.1 & 4.47 & 12.3 & 6 & 6 & 7.7 \\
\hline Lungs (g) & 13 & 13.9 & 13 & 7.88 & 8 & 9.65 & 7.44 & 8 & 14.1 & 8.5 & 8 & 8.45 & 14.1 & 11.3 & 8.46 & 9.52 & 8.44 & 9.24 & 8.9 & 7.17 & 8.5 \\
\hline State & D & D & D & S & D & D & S & S & S & D & D & D & D & D & D & S & $\mathrm{S}$ & D & D & $\mathrm{S}$ & \\
\hline
\end{tabular}

F= Female ; M= Male ; Dark grey and bold: High value ; Light grey : Low value ; State D= Dead ; State S= Survivor 


\section{Isolated organ weights of envenomated rabbits treated curatively}

In Table 3, the values of the isolated and weighed organs of the envenomed rabbits treated as a curative measure (portion E3) are presented. The analysis of the weight of their respective organs shows that:

- in lot 9, the heart is simultaneously large in all three females whereas the liver, lungs and kidneys are large in two females in contrast to the lungs in one female of the lot. Other than these findings, the liver and kidneys were normal in two different females. This lot is distinguished by the death of two of the three females.

- In batch 10, all vital organs were increased in volume in one female, as were the lungs in all animals in the batch. Apart from these observations, the heart, liver and kidneys were normal in two females in the batch. It is characterized by the death of one individual out of the three.

Table 3: Isolated organ weights of envenomated rabbits treated as a cure

\begin{tabular}{cccccccc} 
& \multicolumn{2}{c}{ Lot 1 : Envenomed } & \multicolumn{3}{c}{ Lot 9 } & \multicolumn{3}{c}{ Lot 10 } \\
\cline { 2 - 8 } Weight (Kg) & F4 & F9 & F8 & F5 & F15 & F16 & F17 \\
\cline { 2 - 8 } Heart (g) & 1.9 & 1.7 & 2 & 2 & 1.9 & 1.74 & 2.2 \\
Liver (g) & $\mathbf{7 . 0 2}$ & $\mathbf{9 . 7 1}$ & $\mathbf{8 . 1}$ & $\mathbf{8 . 8 6}$ & 5.02 & $\mathbf{7 . 1 2}$ & 6 \\
Kidneys (g) & $\mathbf{6 9 . 4}$ & 51.6 & $\mathbf{7 7 . 1}$ & $\mathbf{7 0 . 3}$ & 60.4 & $\mathbf{6 5 . 3}$ & 63 \\
Lungs (g) & $\mathbf{6 . 8}$ & $\mathbf{6 . 8}$ & 5.9 & $\mathbf{7 . 4 9}$ & 5.8 & $\mathbf{6 . 5 7}$ & 5.94 \\
State & $\mathbf{8 . 4 5}$ & 4.9 & $\mathbf{8 . 6}$ & $\mathbf{1 0 . 7}$ & $\mathbf{8 . 4 5}$ & $\mathbf{8 . 4 6}$ & $\mathbf{8 . 5}$ \\
\multicolumn{2}{c}{ F= Female; M= Male; Dark grey and bold: High value; Light grey: Low value; State D= Dead; State S= Survivor } & & S
\end{tabular}

\section{DISCUSSION}

\section{Isolated organ weights of untreated control and envenomed rabbits}

Regarding the macroscopic analysis, it can be said that the heart and lungs weigh more in males than females because their respective reference values are 4.51 to $8.70 \mathrm{~g}$ and 4.48 to $6.63 \mathrm{~g}$; and 6.50 to $8.03 \mathrm{~g}$ and 5.66 to $7.07 \mathrm{~g}$. On the other hand, the liver and kidneys of females, which are 51.56 to $64.66 \mathrm{~g}$ and 5.01 to $5.95 \mathrm{~g}$ respectively, weigh more than those of males (49.68 to $64.30 \mathrm{~g}$ and 4.94 to $6 \mathrm{~g}$ ). The reference values obtained in this study are similar to those of ${ }^{11}$ for liver; ${ }^{3}$ for heart and ${ }^{23}$ for kidney.

If for the untreated envenomed rabbits (lot 1), the heart and lungs of one out of two males and the female, and for the liver and kidneys of both males and the female have their respective organ is above the norms, it would mean that the snake venom has certainly more action on these organs mentioned above. Thus in general, the venom would induce on these isolated organs of these untreated envenomed rabbits, an increase in their volume. In addition, besides this noticed increase, the isolated organs are generally degraded. Therefore, the increased volume of certain organs and the degraded or dilated appearance observed on these organs could be due to certain factors. These factors may include fluid accumulation in the interstitial zone and tissue necrosis. Necrosis may be caused by cytotoxins that induce gangrene in these organs, while the accumulation of fluid in the interstitial zone is the cause of edema. Indeed, according to ${ }^{10}$, the venoms of Elapidae possess cytolytic toxins. This cytolysis can cause necrosis which can lead to gangrene. These gangrene can expose vital organs to anaerobic germs and superinfection ${ }^{19}$. So, the degraded state of the different organs obtained in this study can be explained by this state of affairs. According to ${ }^{13}$, the dose of $2 \mathrm{mg} / \mathrm{Kg}$ body weight of Naja nigricollis venom injected in this study can cause a decrease in blood pressure (hypotension). This decrease is due to the cytotoxins of this venom. ${ }^{21}$ reveal that the decrease in this blood pressure would be at the origin of the formation of edemas observed on certain organs. These edemas would in turn be at the origin of the increase in volume of certain vital organs. ${ }^{17}$ also shows that the increase in volume of the cell which becomes waterlogged seems to be linked to a disruption of ionic exchanges on both sides of the membrane, which makes it possible to suppose that cytotoxins act at the level of ionic channels, in particular sodium. They depolarize the cytoplasmic membrane of excitable cells. Consequently, the increase in volume of the organs studied in this study would obey these principles.

\section{Isolated organ weights of preventively treated and envenomated rabbits}

The increase in weight of the vital organs of batch 2 treated with P1 (ashes of the two plants and the viper skull) indicates an increase in the volume of these organs. This would be the cause of death of the individuals in this batch. Therefore, this increase in volume would show that this potion could not have had any protective action against the injected venom. This ineffectiveness of P4 (viper skull ash) and P5 (Mucuna pruriens and Millettia pinnata ash) on lot 5 and lot 6 respectively is observed because all the animals in these various lots died. In batches 5 and 6 , this death was generally due to an increase in the volume of vital organs (heart, liver, kidneys and lungs). Batches 3 and 8 treated respectively with P2 (ash of Mucuna pruriens) and P7 (ash of viper skull and Millettia pinnata) saved one individual out of three of these batches by preserving all the vital organs of one male. Thus, these potions would have a protective action on these organs against the venom. Batch 7 treated with P6 (ashes of viper skull and Mucuna pruriens) kept two individuals alive by protecting all the vital organs such as the heart, liver and kidneys against venom. As for the use of P3 (Millettia pinnata ash) for the care of batch 4, it allowed the survival of the three individuals of the batch by protecting overall the organs such as heart, liver and lungs against the venom. 


\section{Isolated organ weights of envenomated rabbits treated curatively}

The treatment of batch 9 with P1 (ashes of the two plants and the viper skull) kept one individual out of three alive by protecting the kidneys against the venom. The use of P3 (ash of Millettia pinnata) for the treatment of lot 10 allowed the survival of two out of three individuals by protecting vital organs such as the heart, liver and kidneys against the venom.

\section{CONCLUSION}

Finally, this study revealed that in general :

- the heart and lungs of male rabbits weigh more than those of females, while the liver and kidneys do not.

- the venom of Naja nigricollis induces in a general way an increase in the volume and a degradation of the vital organs at the origin of necrosis. The necrosis is due to the cytotoxins of the venom which causes gangrene of these organs. These gangrene can expose the vital organs to anaerobic germs and to a superfection.

- the dose of venom injected ( $2 \mathrm{mg} / \mathrm{Kg}$ of body weight) can cause hypotension (drop in blood pressure) which can lead to the formation of oedemas and consequently to gangrene (hypertrophy of organs).

- The use of P2 (ash of Mucuna pruriens) as a preventive measure has saved one individual out of three by preserving all the vital organs of a male. Thus, this potion has a protective effect on these organs against the venom.

- the preventive use of P3 (Millettia pinnata ash) allowed the survival of all three animals by protecting organs such as the heart, liver and lungs against the venom.

- the application of P3 (ash of Millettia pinnata) as a curative measure kept alive two out of three individuals by protecting vital organs such as the heart, liver and kidneys against the venom.

\section{CONFLICTS OF INTEREST}

Authors declare that there are no conflicts of interest in relation to the publication on this manuscript.

\section{REFERENCES}

1. Adjanohoun EJ, Aké-Assi L. Contribution to the census of medicinal plants in Côte d'Ivoire CRES. National Center of Floristics, University of Côte d'Ivoire. 1979; 358 p.

2. Anonymous. Envenomations in the Medical Encyclopedia of Africa. Larousse Afrique 4, Belgium. 1986; 1111-1115.

3. Aouimeur A, M'Ziane K. Biochemical and histological characteristics of the heart in relation to vitamin $\mathrm{C}$ coadministration in male rabbits treated with Avimec. Master in Biology Option: Biological Engineering, Faculty of Natural and Life Sciences, Blida 1 University, Algeria. 2017; 80 p.

4. Arfaoui A, Hmimou R, Ouammi L, Soulaymani A, Mokhtari A, Chafiq F, Soulaymani-Bencheick R. Epidemiological profile of snakebites in Morocco. Journal of Venomous Animals and Toxins including Tropical Diseases. 2009; 15(4):653-666. https://doi.org/10.1590/S1678-91992009000400005

5. Chippaux JP. Snake bite epidémiology in Bénin (West Africa). Toxicon. 1989; 27:127-135. https://doi.org/10.1016/00410101(89)90259-6

6. Chippaux JP. Snakebites in intertropical Africa. Health booklet. 1992; 2(4):221-234.
7. Chippaux JP. Snake bites: appraisal of the global situation. Bulletin of World Heath Organisation. 1998; 76(5):515-524.

8. Chippaux JP. The snakes of West and Central Africa. Tropical Fauna and Flora Collection. 2006; 35:11-329.

9. Coulibaly SK, Hami H, Hmimou R, Mokhtari A, Soulaymani R, Maiga A, Soulaymani A. Ophidian envenomations in the Koulikoro region of Mali. Antropo. 2013; 29:41-47. www.didac.ehu.es/antropo.

10. Diarra A. Epidemiological, clinical and therapeutic aspects of snakebites in the national hospitals of Mali. Doctorate in Medicine, Faculty of Medicine, Pharmacy and Odontostomatology, University of Bamako, Mali. 2006; 70 p.

11. Djamila S. Study of the effects of Switch (Fludioxonil and Cyprodinil) on the liver of the rabbit "Oryctolagus cuniculus". Doctorate in Veterinary Science, Institute of Veterinary Sciences, University Saad Dahlad Blida1, Algeria. 2018; 52 p.

12. El Koraichi A, Tsala G, El Haddoury M, Ech-chérif El Kettani S. Epidemiology of viper bite envenomations in the pediatric intensive care unit at the children's hospital of Rabat, Morocco. French Annals of Anaesthesia and Resuscitation. 2011; 30 (1):83-85. https://doi.org/10.1016/j.annfar.2010.11.003

13. Fumba G. Anti-venomous medicinal plants from Burundi. Presses of the future, Arlon, Belgium. 1983; 136 p.

14. Gentilini M. Venomous animals, Flammarion medicine science: 5 th edition Paris. 1993 ; 682 p.

15. Goyffon M, Chippaux JP. Terrestrial venomous animals. MedicalSurgical Encyclopedia. 1990; 14 p.

16. Grema M, Koné PP. Effects of the venom of a snake (Bitis arietans) and an antivenomous plant of the traditional African pharmacopoeia (Annona senegalensis) on the sciatic nervegastrocnemius junction of a toad (Buffo regularis). CAMES Journal. 2003; Series A(02): 79-85.

17. Kassogué A. Renal complications of snake bite envenomations at the SUC HGT from January to December 2004. Doctorate in Medicine, Faculty of Medicine, Pharmacy and Odontostomatology, University of Bamako, Mali. 2006; 86 p.

18. Koné PP. Toxicological, electro-physiological and pharmacological study of the venom of Naja nigricollis (Elapidae from Côte d'Ivoire) and of an anti-venomous substance of the African pharmacopoeia, the aqueous extract of Securidaca longepedunculata. Doctoral thesis, UFR des Sciences, University of Côte d'Ivoire. 1980; 172 p.

19. Manaoui R. Snake bites in the region of Marrakech Tensift el Haouz. Doctorate in Medicine, Faculty of Medicine and Pharmacy, Cadi Ayyad University of Marrakech, Morocco. 2007; $73 \mathrm{p}$.

20. Okou OC. Efficacy and spectrum of activity of extracts of Mitracarpus scaber Zucc. ex Schult + Scult.f. (Rubiaceae) and fusidic acid on Gram-positive Cocci Bacteria. Doctoral thesis in Biochemistry-Pharmacology, Université Félix HouphouëtBoigny, Abidjan, Côte d'Ivoire. 2012; 229 p

21. Roch A, Allardet S. Pathophysiology of edema. Resuscitation. 2007; 16:102-110. https://doi.org/10.1016/j.reaurg.2006.12.011

22. Somé N, Poda JN, Guissou IP. Epidemiology and management of ophidian envenomations in the district of Dano health, Ioba province (Burkina Faso) from 1981 to 2000. Envenomation and its treatment in Africa. Bulletin de la Société Pathologique Exotique. 2002; 95(3):163-166.

23. Zerrout N. Effect of vitamin C co-administration on the kidney in male rabbits treated with ivermectin. Master's thesis in Biology Option: Biological Engineering, Faculty of Natural and Life Sciences, Blida 1 University, Algeria. 2016; 63 p 